\title{
PERBEDAAN PENGARUH ANTARA TRANSCUTANEUS ELECTRICAL NERVE STIMULATION (TENS) DENGAN TERAPI MASSAGE TERHADAP PENURUNAN NYERI PADA PENDERITA NYERI PUNGGUNG BAWAH NON SPESIFIK
}

\author{
Septi Ayu Arum Yuspita Sari \\ Pascasarjana Ilmu Kesehatan Masyarakat Universitas Sebelas Maret
}

\begin{abstract}
Non Specific Low Back Pain, Transcutaneus Electrical Nerve Stimulation (TENS), Massage Therapy. The cause of the symptoms of non specific low back pain is the mechanics factor because over load of the spine. Transcutaneus electrical nerve stimulation (TENS) and massage therapy is a method that can be used to decrease pain caused by the occurrence of non specific low back pain. This study aimed to investigate the effect and influence of the difference between TENS with massage therapy to decrease of pain in patients with non specific low back pain. This study employed with experimental two group pre test and post test design. Twelve patients with non specific low back pain were randomly divided into two groups: TENS (group 1) and massage therapy (group 2). All patients were evaluated before and after treatment using a visual analog scale. Mann whitney test hypothesis testing in the group of TENS obtained $Q V A S$ value $p=0,026$, while in the group massage therapy obtained $Q V A S$ value $p=$ 0,024 are statistically significant decrease pain. Wilcoxon test result hypothesis between TENS with massage therapy obtained after treatment $p=0,004$ means there is significant difference between TENS with massage therapy. TENS was more effective in improving pain than massage therapy for patient with non specific low back pain.
\end{abstract}

Keywords: Non Specific Low Back Pain, Transcutaneus Electrical Nerve Stimulation (TENS), Massage Therapy

Abstrak : Nyeri Punggung Bawah Non Spesifik, TENS, Terapi Massage. Salah satu
penyebabnya timbulnya keluhan nyeri punggung bawah adalah faktor mekanik berupa
pembebenan yang berlebihan pada tulang belakang. TENS dan terapi massage
merupakan metode yang dapat digunakan untuk mengurangi nyeri akibat terjadinya
nyeri punggung bawah non spesifik. Penelitian ini bertujuan untuk mengetahui
pengaruh dan perbedaan pengaruh antara TENS dengan terapi massage terhadap
penurunan nyeri pada pasien nyeri punggung bawah non spesifik. Penelitian ini
menggunakan desain penelitian experimental two group pre test and post test design.
Dua belas orang pasien dibagi menjadi 2 kelompok secara random: TENS (kelompok 1)
dan terapi massage (kelompok 2 ). Semua pasien akan dievalusi menggunakan alat ukur
nyeri berupa visual analog scale pada sebelum dan seseudah intervensi. Uji hipotesis
mann whitney test pada kelompok perlakuan TENS diperoleh nilai QVAS p $=0,026$
sedangkan pada kelompok perlakuan terapi massage diperoleh nilai QVAS p $=0,024$
yang berarti pada statistik terdapat penurunan nyeri pada nyeri punggung bawah non
spesifik. Hasil uji hipotesis wilcoxon test antara perlakuan TENS dengan terapi massage
setelah perlakuan diperoleh nilai p $=0,004$ yang berarti terdapat perbedaan dalam 
penurunan nyeri antara pelakuan TENS dengan terapi massage. TENS lebih efektif dibandingkan dengan terapi massage untuk mengurangi keluhan nyeri pda pasien nyeri punggung bawah non spesifik.

Kata Kunci: Nyeri Punggung Bawah Non Spesifik, TENS, Terapi Massage

\section{PENDAHULUAN}

Prevalensi nyeri muskuloskeletal, termasuk nyeri punggung bawah, telah dideskripsikan sebagai sebuah epidemik. Keluhan nyeri biasanya self limiting, tetapi jika menjadi kronik, konsekuensinya serius. Nyeri punggung bawah menyebabkan turunnya produktivitas seseorang. Banyak penyebab nyeri muskuloskeletal telah diidentifikasi. Faktor-faktor psikologis dan sosial berperan besar dalam eksaserbasi nyeri dengan mempengaruhi persepsi nyeri dan perkembangan disabilitas kronik (Barua \& Sultana, 2015).

Nyeri punggung bawah (NPB) merupakan kelainan muskulokeletal yang paling sering terjadi akibat kerja. Penyakit akibat kerja adalah penyakit artefisial yang timbulnya disebabkan oleh pekerjaan manusia (Effendi, 2011). Kemajuan di bidang industri telah membawa kemudahan bagi hidup manusia, namun demikian, masih terdapat persoalanpersoalan dalam dunia kerja yang tidak dapat diatasi dengan teknologi yang ada, sehingga interaksi antara pekerja dengan lingkungan dan alat kerja dapat menimbulkan dampak negatif bagi pekerja (Basuki, 2009).

Hampir $20 \%$ orang mengalami nyeri punggung bawah setiap tahunnya dan hanya sekitar $10-20 \%$ saja yang ditemukan diagnosisnya secara pasti. Paling banyak adalah nyeri punggung bawah mekanik yaitu $97 \%$ dari seluruh kasus nyeri punggung bawah. Sebanyak 90\% keluhan akan hilang dalam waktu kurang lebih 2 minggu-3 bulan setelah onset (Barua \& Sultana, 2015).

Nyeri punggung bawah suatu masalah yang umum terjadi dalam masyarakat, dengan prevalensi berkisar antara 12\% - 33\%. Prevalensi 1 tahun mencapai $22 \%$ - $65 \%$ dan prevalensi seumur hidup mencapai $11 \%$ - 84\%. Selain itu nyeri punggung bawah biasanya bersifat self-limiting (dapat bertahan dalam jangka waktu yang lama) sehingga dapat membebani kehidupan pribadi, sosial, dan ekonomi seseorang (Walker \& Williamson, 2009).

Penyebab nyeri punggung bawah secara garis besar terbagi menjadi dua, yaitu nyeri punggung bawah non-spesifik dan spesifik. Nyeri punggung bawah nonspesifik disebabkan oleh regangan otot, ligamen, bantalan antar tulang dan sendi yang biasanya disebabkan oleh cidera. Nyeri punggung bawah non-spesifik atau juga disebut nyeri punggung bawah nonradikuler adalah nyeri punggang bawah yang tidak ditemukan adanya gejala dan tanda neurologik. Pada beberapa kepustakaan disebutkan bahwa nyeri punggung bawah non-spesifik diakibatkan oleh strain atau sprain (Pattinama, 2013).

Nyeri punggung bawah non spesifik hakekatnya adalah merupakan keluhan atau gejala dan bukan merupakan penyakit yang spesifik. Sekitar 90\% NPB non spesifik akut maupun kronis biasanya sumbuh spontan dalam waktu 4 minggu sampai 6 minggu, cenderung berulang dan insidennysa sekitar 15\%-20\%. Kelainan yang mendasarinya ialah karena faktor 
mekanik yaitu pembebanan yang berlebihan pada punggung bawah sehingga terjadi cidera pada otot (strain) dan atau ligamen (sprain). Gangguan mekanik ini lokasinya terbatas pada jaringan disekitar lumbosacral (Arbain, 2010).

Sebagian besar NPB non spesifik merupakan gangguan yang bersifat self limiting (dapat sembuh dengan sendirinya) (Barua \& Sultana, 2015). Sekitar $50 \%$ penderita mengalami perbaikan dalam waktu 2 minggu dan kurang lebih $90 \%$ penderita membaik dalam waktu 8 minggu. Hampir 95\% pasien sembuh dalam waktu 6 bulan. Angka kekambuhan NPB non spesifik cukup tinggi, sekitar $60 \%$ dari seluruh penderita mengalami kekambuhan dalam waktu 1 tahun (Elders \& Burdoff, 2004).

Sinar infra merah merupakan salah satu intervensi fisioterapi yang bisa digunakan untuk penenganan nyeri punggung bawah. Panas yang dihasilkan oleh lampu infra merah banyak digunakan di klinik fisioterapi untuk menangani kondisi musculoceletal termasuk nyeri punggung bawah. Radiasi yang dihasilkan oleh pancaran lampu infra merah dapat meningkatkan aliran darah dan rileksasi jaringan, sehingga berpotensi mengurangi nyeri dan memaksimalkan fungsi pada penderita nyeri punggung bawah (Ansari, 2014).

Menurut Kuntono (2005), dengan pancaran sinar infra merah (IR) pada punggung bawah terjadi stimulus termoreseptor pada punggung bawah sehingga mengakibatkan vasomotor dilatator kapiler teraktivasi dan diikuti oleh vasodilatasi pembuluh darah kapiler. Vasodilatasi kapiler secara berkesinambungan akan memberikan suatu respon terhadap kapiler regional pada otot, sehingga meningkatkan vaskularisasi otot. Termoreseptor juga memberikan efek sedatif pada sensoris nerve ending di kulit yang bermanfaat untuk meningkatkan rileksasi otot pada nyeri punggung bawah, sehingga fase nyeri berkurang.

TENS merupakan modalitas fisioterapi yang paling sering digunakan untuk mengatasi nyeri, misalnya untuk kasus-kasus trauma, inflamasi, cidera, seperti wiplash injury dan nyeri punggung bawah. TENS dapat digunakan untuk nyeri kronis dan akut pada segala kondisi (Facci et al., 2011). TENS menghasilkan arus yang akan disampaikan ke permukaan kulit punggung bawah melalui elektrode. TENS yang diaplikasikan pada punggung bawah akan menimbulkan tanggap rangsang fisiologis dari jaringan yang bersangkutan baik sebagai akibat langsung maupun tidak langsung. Pengaruh langsung terjadi di tingkat sel, jaringan, segmental maupun sistim (Gad Alon, 1987 dikutip oleh Parjoto, 2006).

Penggunaan AL-TENS terbukti bermanfaat dalam mengurangi nyeri pada beberapa penelitian yang sudah dilakukan sebelumnya. Penelitian Facci et al. (2011) pada subjek dengan diagnosis nyeri punggung bawah menyimpulkan bahwa terjadi penurunan nyeri dengan penggunaan TENS ber durasi $330 \mu$ detik dan frekuensi $20 \mathrm{~Hz}$.

Tujuan tranverse friction adalah membantu menghancurkan myloglosis, yaitu timbunan sisa-sisa pembakaran energi (asam laktat) yang terdapat pada otot yang menyebabkan pengerasan pada otot, (3) Petrissage merupakan manipulasi menggunakan kedua tangan yang terdiri dari perasan, tekanan, atau pengangkatan otot dan jaringan dalam secara perlahanlahan sebanyak 6 kali pada setiap titik. 
Untuk teknik ini area punggung bawah dapat dibagi menjadi 2 titik. Perlakuan sama denagn tranversa friction, diaplikasikan pada punggung sebelah kanan dan kiri. Manfaat dari teknikpetrissageadalah membebaskan otot dari penumpukan sisa metabolisme, membantu melancarkan aliran vena dan membantu membebaskan jaringan fibrous. Efek petrissage sangat berguna pada saat terjadi kelelahan otot, (4) kneading adalah suatu manipulasi otot yg dilakukan dengan menekan dan memeras otot secara pelan dan hati-hati dengan menggunakan telapak tangan. Palmar kneding adalah salah stu teknik kneading yang pengaplikasiannya menggunakan telapak tangan bagian palmar. Pengaplikasian teknik ini pada area punggung bawah sama dengan teknik tranverse friction, tetapi area punggung bawah dibagi menjadi 3 titik (Hernandez-reif et al., 2000).

dengan teknik $\begin{array}{rr}\text { Penggunaan } & \text { terapi } \\ \text { swedish } & \text { massage }\end{array}$
(effleurage, friction, petrissage, kneading, tapotemen dan skin rolling) terbukti bermanfaat untuk mengurangi spasme pada otot dan memberikan efek sedatif serta rileksasi terhadap jaringan (Davies, 2000).

Penelitian yang relevan mengenai intervensi yang efektif untuk mengurangi keluhan nyeri punggung bawah non spesifik adalah penelitaian yang dilakukan oleh Preyde (2000) dengan judul pennelitian "Effectiveness of massage therapy for subacute low-back pain": A randomized controlled trial. Tujuan penelitian ini adalah untuk mengevaluasi efektifitas massage terhadap pengurangan nyeri pada pasien nyeri punggung bawah sub akut. Subjek penelitian ini adalah penderita nyeri punggung bawah sub akut dan dilakukan random menjadi 4 group: terapi massage $(\mathrm{n}=25)$, soft-tissue manipulation $(\mathrm{n}=25)$, remedial exercise dan edukasi postur $(n=22)$ dan placebo dari infra red therapy $(n=26)$. Setiap subyek mendapatkan 6x treatmen selama1 bulan, dengan hasil subyek yang menerima terapi massage melaporkan tingkat penurunan nyeri yang signifikan dibandingkan dengan subyek yang mendapatkan treatmen yang lain $(\mathrm{p}<0.05)$ (Preyde, 2000).

Penelitian yang dilakukan oleh Facci et al. (2011) dengan judul "Effects of Transcutaneous Electrical Nerve Stimulation (TENS) and Interferential Currents (IFC) in patients with nonspecific chronic low back pain": randomized clinical trial. Tujuan penelitian ini adalah untuk mengevaluasi efektifitas TENS terhadap pengurangan nyeri pada pasien nyeri punggung bawah non spesifik kronik. Subyek penelitian ini adalah penderita nyeri punggung bawah non spesifik kronik dan dilakukan random menjadi 3 group: 1) TENS ( $\mathrm{n}=50) ; 2)$ interferential current $(\mathrm{n}=50)$; 3) dan kelompok kontrol $(\mathrm{n}=50)$. Setiap subyek mendapatkan $10 \mathrm{x}$ treatmen selama 1 bulan, dengan hasil subyek yang menerima tretmen berupa TENS dan interferential current melaporkan samasama mengalami tingkat penurunan nyeri yang significan dibandingkan dengan kelompok kontrol ( $\mathrm{p}>0,05)$ (Facci et al., 2011).

Meskipun TENS dan terapi
massage dapat diterapkan untuk mengurangi nyeri pada penderita nyeri punggung bawah. Seperti pada penelitian yang dilakukan oleh Hawamdeh et al. (2015) yang menyimpulkan bahwa TENS yang dikombinasikan dengan latihan pengutan otot punggung bawah efektif 
untuk mengurangi nyeri pada penderita nyeri punggung bawah kronik dan penelitian yang dilakukan oleh Hernandez-reif et al. (2000) yang menyimpulkan bahwa terapi massage dengan teknik Swedish massage memberikan efek yang signifikan untuk mengurangi nyeri pada penderita nyeri punggung bawah subakut. Perlu dilakukan penelitian yang lebih lanjut terkait kedua intervensi tersebut, karena kedua intervensi memberikan pengaruh yang sama-sama signifikan terhadap pengurangan nyeri pada penderita nyeri punggung bawah. Penelitian yang lebih lanjut tersebut bertujuan untuk menegetahui mengenai intervensi yang lebih efektif diantara keduanya untuk mengurangi nyeri pada penderita nyeri punggung bawah non spesifik.

Berdasarkan latar belakang tersebut, sangat perlu dilakukan penelitian tentang perbedaan efektivitas antara TENS dengan terapi massage terhadap pengurangan keluhan nyeri pada penderita nyeri punggung bawah non spesifik di RSUD Kota Semarang.

\section{METODE PENELITIAN}

Penelitian ini merupakan penelitian eksperimental, desain penelitian dengan menggunakan two groups pre and post test design yaitu membandingkan antara kelompok perlakuan satu yang menggunakan TENS dengan kelompok perlakuan dua yang menggunakan terapi massage yang mana sebelum diberi kedua perlakuan tersebut setiap kelompok diberikan perlakuan berupa sinar infra merah.

Penelitian ini menggunakan alat ukur pengukuran nyeri Quadruple Visual Analog Scale (Quadruple VAS). Quadruple VAS digunakan untuk menilai intensitas nyeri dan dianggap dapat menjadi metode yang akurat, sensitif dan dapat dikembangkan sebagai pengukuran persepsi nyeri. Skala ini digunakan untuk penilaian intensitas nyeri di empat tingkat, yaitu nyeri saat ini, nyeri rata- rata dalam 24 jam terakhir, nyeri paling ringan dan nyeri paling berat. Pengukuran nyeri dilakukan menggunakan gambaran garis mendatar (horizontal) sepanjang $10 \mathrm{~cm}$, pada awal garis diberikan keterangan tidak nyeri pada angka 0 dan pada akhir garis diberi angka 10. Sebelum melakukan pengisian pengukuran, subyek diberikan penjelasan tentang cara pengukuran dan diberi instruksi untuk melingkari angka yang tertera pada garis Quadruple VAS dihitung sesuai pada angka yang dilingkari oleh subyek. Setelah pengukuran, dilakukan pengambilan data yaitu saat pertama kali kunjungan sebelum mendapatkan terapi dan setelah mendapatkan sepuluh kali terapi (Von Korff, 1993 dikutip oleh Ogunlana et al. 2012).

Tahap persiapan dilakukan meliputi proses perijinan. Pada tahap perijinan ini dilakukan pengurusan ijin penelitian kepada Direktur RSUD Kota Semarang dan pihak terkait (Kepala Instalasi Rehabilitasi Medik, Kepala Ruang Poli Fisioterapi dan Kasi Diklat RSUD Kota Semarang). Setelah proses perijinan selesai, peneliti memberikan penjelasan kepada rekan sejawat yang bersedia membantu dalam proses penelitian ini, tentang cara pengukuran nyeri menggunakan Quadruple VAS dan penerapan terapi massage. Hal ini dilakukan untuk menyamakan persepsi antara peneliti dengan rekan sejawat, dalam pengukuran nyeri menggunakan Quadruple VAS dan penerapan terapi massage. 


\section{HASIL PENELITIAN}

Berdasarkan data yang telah diperoleh, pada kelompok I jumlah subyek laki-laki lebih banyak dibanding subyek perempuan, yaitu laki-laki berjumlah 4 orang dengan prosentase $66,7 \%$ dan perempuan berjumlah 2 orang dengan prosentase $33,3 \%$. Sedangkan pada kelompok II jumlah subyek perempuan lebih banyak dibanding subyek laki-laki, yaitu perempuan berjumlah 4 orang dengan prosentase $66,7 \%$ dan laki-laki berjumlah 2 orang dengan prosentase $33,3 \%$.

Karakteristik subyek penelitian berdasarkan jenis kelamin mempunyai prosentase yang sama. Jenis kelamin lakilaki dan jenis kelamin perempuan mempunyai faktor resiko yang sama untuk menderita nyeri punggung bawah non spesifik. Menurut Toraman et al. (2014). jenis kelamin, laki- laki dan perempuan mempunyai resiko NPB non spesifik yang sama sampai usia sekitar 60 tahun. Hal ini terkait dengan proses degeneratif dan osteoporosis.

Usia antara 21-30 tahun pada kelompok I terdapat 1 orang dengan prosentase $16,7 \%$ sedangkan pada kelompok II terdapat 2 orang dengan prosentase $33,3 \%$. Kemudian usia antara 31-40 tahun pada kelompok I terdapat 5 orang dengan prosentase 83,3\% sedangkan pada kelompok II terdapat 4 orang dengan prosentase $66,7 \%$. Faktor resiko dari NPB non spesifik salah satunya adalah faktor individu. Faktor individu yang sering berkaitan dengan NPB non spesifik adalah usia, di Amerika Serikat sering terjadi pada pekerja berat pada usia 45 tahun, namun dari berbagai studi epidemiologi kejadian NPB non spesifik miningkat pada usia 35 tahun dan mencapai puncaknya pada usia sekitar 55 tahun.

Pada kelompok I jumlah subyek yang memiliki pekerjaan PNS sebanyak 2 orang dengan prosentase 33,3\%, wiraswasta sebanyak 3 orang dengan prosentase $50 \%$, ibu rumah tangga sebanyak 1 orang dengan prosentase $16,7 \%$ dan mahasiswa tidak ada dengan prosentase $0 \%$. Sedangkan pada kelompok II jumlah subyek yang memiliki pekerjaan PNS sebanyak 1 orang dengan prosentase $16,7 \%$, wiraswasta sebanyak 1 orang dengan prosentase $16,7 \%$, ibu rumah tangga sebanyak 2 orang dengan prosentase $33,3 \%$ dan mahasiswa sebanyak 2 orang dengan prosentase $33,3 \%$.

Dalam penilitian ini jumlah subyek yang menderita NPB non spesifik serbagian besar bekerja sebagai wiraswsata, menurut data yang diperoleh pekerjaan wiraswasta tersebut meliputi pedagang di pasar, pemilik salon dan pemilik warung makan yang menagharuskan pasien sering meelakukan kegiatan menganggkat, menggeser barang, berdiri dalam posisi yang lama, duduk dalam posisi yang lama dan sering melakukan aktivitas membungkuk serta memutar.

Hasil pengukuran tingkat nyeri sebelum perlakuan I menunjukkan bahwa hasil quadruple VAS minimal adalah 6, quadruple VAS maksimal 7 dan standart deviasi 0,44721 dengan jumlah subyek 6 orang. Hasil pengukuran tingkat nyeri sebelum perlakuan II menunjukkan bahwa hasil quadruple VAS minimal adalah 5, quadruple VAS maksimal 7 dan standart deviasi 0,66458 dengan jumlah subyek sebanyak 6 orang. Rata-rata nila quadruple VAS sebelum perlakuan pada kelompok I dan II menunjukkan bahwa 
kelompok I memiliki nilai mean 6,5 dan kelompok II memiliki mean 6,083.

Pada uji pre test antara kedua kelompok ini diperoleh hasil data pre test pada kelompok I dan kelompok II tidak ada perbedaan yang bermakna antara dua kelompok data atau data tersebut bersifat homogen. Hasil uji beda pre test kelompok I dan kelompok II dapat dilihat pada tabel I berikut.

Tabel 1

Hasil Uji Homogenitas Pre Test Antara Kelompok I dan Kelompok II

\begin{tabular}{lll}
\hline & $p$ & Keterangan \\
\hline $\begin{array}{l}\text { Pre-test kelompok I } \\
\text { dan II }\end{array}$ & 0.238 & Data homogen \\
\hline
\end{tabular}

Uji beda pre dan post test pada kelompok I memberikan hasil uji pre dan post test pada kelompok I terdapat perbedaan pengaruh. Hasil uji nilai prepost pada kelompok I dapat dilihat pada tabel 2 berikut.

Tabel 2

Hasil Uji Beda Pre-Post Test Pada Kelompok I

\begin{tabular}{llll}
\hline & $\mathrm{n}$ & $P$ & keterangan \\
\hline pre & 6 & 0,026 & $\begin{array}{l}\text { Ada beda } \\
\text { bermakna }\end{array}$ \\
post & 6 & & \\
\hline
\end{tabular}

Sedangkan uji beda pre dan post test pada kelompok II memberikan hasil uji pre dan post test pada kelompok II terdapat perbedaan pengaruh. Hasil uji nilai pre-post pada kelompok II dapat dilihat pada tabel 3 berikut.

Tabel 3

Hasil uji beda pre-post test pada kelompok II

\begin{tabular}{llll}
\hline & $\mathrm{n}$ & $P$ & keterangan \\
\hline pre & 6 & 0,024 & $\begin{array}{l}\text { Ada beda } \\
\text { bermakna }\end{array}$ \\
post & 6 & & \\
\hline
\end{tabular}

Uji beda post test antara kedua kelompok diperoleh hasil $\mathrm{p}=0,004$, maka data post test pada kelompok I dan kelompok II ada perbedaan yang bermakna antara dua kelompok data tersebut.

Nilai mean QVAS pada kedua kelompok sebelum dan setelah perlakuan, pada kelompok I selisih mean sebelum dan setelah perlakuan sebesar 3,7917 sedangkan pada kelompok II selisih mean sebelum dan setelah perlakuan sebesar 2,0416 maka dapat disimpulkan bahwa kelompok I mempunyai pengaruh yang lebih baik terhadap penurunan nilai QVAS dibandingkan kelompok II, dimana TENS dan sinar infra merah lebih baik dibandingkan terapi massage dan sinar infra merah. Selisih mean pada kelompok I dan II dapat dilihat pada tabel 4 berikut.

Tabel 4

\section{Selisih Mean Pada Kelompok Dan} Kelompok II

\begin{tabular}{llll}
\hline & $\begin{array}{l}\text { mean } \\
\text { post test }\end{array}$ & $\begin{array}{l}\text { Mean } \\
\text { post test }\end{array}$ & $\begin{array}{l}\text { Selisish } \\
\text { mean }\end{array}$ \\
\hline $\begin{array}{l}\text { QVAS } \\
\text { kelompo }\end{array}$ & 6,5000 & 2,7083 & 3,7917 \\
k I & & & \\
QVAS & 6,0833 & 4,0417 & 2,0416 \\
kelompo & & & \\
k II & & & \\
\hline
\end{tabular}

\section{PEMBAHASAN}

Pada penelitian kelompok I dengan pemberian intervensi IR dan TENS terjadi pengurangan nyeri pada akhir intervensi. Hal ini dikarenakan adanya mekanisme pengurangan nyeri oleh AL-TENS menghasilkan efek analgesia terutama melalui mekanisme ekstrasegmental yaitu dengan jalan menginduksi aktivitas aferen yang berdiameter kecil juga menghasilkan analgesia tingkat ekstrasegmental melalui aktivasi struktur yang membentuk jalanan 
inhibisi desendern seperti periaqueductal grey (PAG), nucleus raphe magnus dan nucleus raphe gigantocelluraris. Kontraksi otot fasik yang dihasilkan oleh AL-TENS akan membangkikan aktivitas aferen motorik kecil (ergoreseptor) yang berujung pada aktivasi jalanan inhibisi nyeri desendern. Dalam hubungannya dengan endorfin AL-TENS lebih berkolerasi dengan mediator endorfin dibandingkan dengan TENS konvensional (Parjoto, 2006).

Pada kelompok I juga diberikan intervensi berupa sinar infra merah (IR) yang bertujuan dapat meningkatkan efek sedatif pada jaringan. Mekanisme pengurangan nyeri dengan sinar infra merah yaang diberikan dengan mild heating akan menyebabkan efek sedatif pada superficial sensory nerves ending (ujung-ujung saraf sensoris superficial) sehingga terjadi pengurangan rasa nyeri (Susilowati, 2011).

Berdasarkan hasil penelitian pada kelompok perlakuan II dengan pemberian intervensi berupa infra merah (IR) dan terapi massage terjadi pengurangan nyeri antara sebelum dan sesudah intervensi. Pada kelompok II selain diberikan intervensi berupa sinar infra merah pasien juga diberikan intervensi berupa terapi massage. Terapi massage yang diberikan dengan intensitas tekanan sedang dengan teknik effleurage, patrisage, palmar kneading, tapotemen dan skin rolling akan merangsang mekanoreseptor. Rangsangan pada mekanoreseptor akan merelease norepinephrine sehingga mengaktivasi serabut saraf berpenampang tebal yang dapat menghambat aktifasi nosiseptor pada tingkat spinal. Efek selanjutnya otot akan menjadi rileks dan nyeri yang dirasakan menjadi berkurang (HernandezReif et al., 2000). Menurut Preyde (2000) dari penelitian yang pernah dilakukan tentang efek terapi massage dibandingkan dengan soft tissue manipulation, remidial exercise dan sham laser treatment pada penderita nyeri punggung bawah sub akut, dalam penelitian tersebut menggunakan metode randomized controlled trial (RCT) dengan jumlah sampel 98 pasien dalam waktu 2 bulan. Kesimpulan dari penelitian tersebut pasien yang mendapat perlakuan berupa terapi massage terjadi penurunan nyeri yang signifikan.

Hasil uji hipotesis terdapat 12 subyek berupa quadruple VAS setelah perlakuan IR dan TENS dengan IR dan terapi massage sebanyak 10 kali dengan nilai probabilitas $(p$ value $)=0,004$ yang berarti terdapat perbedaan yang bermakna antara quadruple VAS setelah perlakuan kelompok perlakuan IR dan TENS dengan IR dan terapi massage. Dengan demikian hipotesis penelitian ini diterima, terdapat perbedaan pengaruh antara IR dan TENS dengan IR dan terapi massage terhadap pengurangan nyeri punggung bwah nonspesifik.

Hasil dari penelitian ini menyatakan bahwa TENS lebih efektif dibandingkan dengan terapi massage untuk penurunan nyeri pada penderita nyeri punggung bawah dengan selisih nilai mean pada kelompok perlakuan TENS adalah 69,5 dan terapi massage adalah 37,2 .

\section{KESIMPULAN DAN SARAN}

Pada penelitian tentang perbedaan pengaruh antara IR dengan TENS dan IR dengan terapi massage terhadap penurunan nyeri pada nyeri punggung bawah non-spesifik yang dilakukan pada tanggal 23 Februari sampai 28 Maret 2015 di RSUD Semarang diperoleh kesimpulan sebagai berikut: (1) terdapat perbedaan 
pengaruh antara sebelum dan setelah diberikan perlakuan pada kelompok I, yaitu berupa IR dengan TENS dengan nilai $\mathrm{p}=0,026$, yang berarti bahwa IR dengan TENS dapat mengurangi nyeri pada nyeri punggung bwawah nonspesifik (2) terdapat perbedaan pengaruh antara sebelum dan setelah diberikan perlakuan pada kelompok II, yaitu berupa IR dengan terapi massage dengan nilai $\mathrm{p}=$ 0,024 , yang berarti bahwa IR dengan terapi massage dapat mengurangi nyeri pada nyeri punggung bawah non spesifik (3) terdapat perbedaan pengaruh yang signifikan antara kelompok I, yaitu perlakuan dengan menggunakan IR dengan TENS dan kelompok II, yaitu perlakuan dengan menggunakan IR dengan terapi massage dengan nilai $\mathrm{p}=$ 0,004, yang berarti bahwa kelompok perlakuan IR dengan TENS dan IR dengan terapi masage memiliki perbedaan pengaruh dalam mengurangi nyeri pada nyeri pungung bawah non spesifik dan (4) IR dengan TENS lebih efektif daripada IR dengan terapi massage dalam pengurangan nyeri pada nyeri punggung bawah non spesifik dengan selisih mean IR dengan TENS lebih besar dibandingkan dengan selisih mean IR dengan terapi massage. Selisih mean untuk perlakuan dengan menggunakan IR dengan TENS adalah 3,7917 sedangkan untuk perlakuan dengan menggunakan IR dengan terapi massage adalah 2,0416.

Berdasarkan

pengalaman

penelitian yang peneliti lakukan di RSUD

Kota Semarang dengan beberapa hambatan dan keterbatasan penelitian. Sebagaimana hambatan penelitian yang dihadapi peneliti dalam penelitian ini adalah sebagian besar diagnosis dokter pada pasien nyeri punggung bawah di RSUD Semarang adalah nyeri punggung bawah dengan kausa spondilosis sehingga perekrutan subyek penelitian yang sesuai dengan kriteria inklusi menjadi terbatas. Selain itu hambatan yang dihadapi peneliti lainnya adalah waktu penelitian yang relatif singkat dan hambatan tehnis di rumah sakit yang menggunakan terapi dasar berupa Micro Wave Diathermi (MWD) sebagai intervensi heating sehingga menyebabkan pelaksanaan penelitian kurang maksimal dan perekrutan subyek penelitian relatif sedikit.

Adapun kelamahan dalam penelitian ini, yaitu: (1) jumlah subyek yang relatif sedikit serta terdapat beberapa subyek yang drop out, sehingga kurang dapat menggambarkan kejadian subyek yang lebih besar (populasi), (2) peneliti tidak dapat mengontrol aktivitas seharihari pasien di luar penelitian yang menyebabkan nyeri muncul kembali setelah diberikan terapi dan (3) peneliti tidak dapat mengontrol medika metosa yang dikonsumsi oleh subyek, sehingga penurunan nyeri belum tentu merupakan hasil dari terapi yang diberikan oleh peneliti.

Maka peneliti menyarankan: (1) perlu dilakukan penelitian yang lebih lanjut dengan jumlah subyek yang lebih banyak agar dapat menggambarkan kejadian subyek yang lebih besar (populasi), (2) pada penelitian ini peneliti melakukan penelitian selama 5 minggu dan perekrutan subyek relatif sedikit, maka dari itu pada penelitian selanjutnya sebaiknya rentang waktu penelitian dilakukan lebih lama daripada penelitian yang sudah dilakukan sebelumnya supaya perekrutan subyek penelitian lebih banyak dan dapat mewakili serta menggambarkan populasi, (3) lebih mengendalikan faktorfaktor yang mempengaruhi (seperti obat 
penurun nyeri dan aktivitas pasien) pada penelitan yang lebih lanjut dan (4) walaupun dengan subyek yang relatif sedikit, peneliti dapat menyimpulkan bahwa terdapat penurunan nyeri pada penderita nyeri punggung bwah non spesifik setelah pemberian IR dan TENS. Berdasarkan hasil penelitian tersebut maka peneliti menyarankan di dalam penetalaksanaan fisioterapi pada kondisi nyeri punggung bawah non-spesifik dapat menggunakan IR dan TENS sebagai salah satu alternatif pilihan.

\section{DAFTAR RUJUKAN}

Ansari, N.N (2014). Effect of therapeutic infra-red in patients with non-s pecific low back pain. Journal of Bodywork \& Movement Therapies, 18, 75-81.

Arbain, S (2010). Pengaruh Myofacial Release Otot dan Fascia Punggung Bawah Terhadap Pengurangan Nyeri Pada Nyeri Punggung Bawah (NPB) Non Spesifik. Politeknik Kesehatan Surakarta, Surakarta.

Barua, S.K. \& Sultana, N (2014). Prevalence of Low Back Pain Among Women Living in Slum Areas of Dhaka City. Chattagram Maa-O-Shishu Hospital Medical College Journal, 14(1), 47-51.

Basuki, K (2009). Faktor Risiko Kejadian Low Back Pain Pada Operator Tambang Sebuah Perusahaan Tambang Nickel Di Sulawesi Selatan. Jurnal Promosi Kesehatan Indonesia, 4(2), 115-121.

Davie, K (2000). Nyeri Tulang Dan Otot. Jakarta: Erlangga.

Effendi, F (2011). A Risk Prediction Model of The Incidence of Occupational Low Back Pain
Among Mining Workers. Medical Journal of Indonesia, 20, 212-216.

Elders,L.A.M. \& Burdoff, A (2004). Prevalence, incidence and recurrence of low back pain in Scaffolders during a three year follow up study. The Spine Journal. 29(6), E101-E106.

Facci, L.M., Nowotny, J.P., Tormem, F. \& Trevisani, V.F.M (2011). Effects of transcutaneous electrical nerve stimulation (TENS) and interferential currents (IFC) in patients with nonspecific chronic low back pain: randomized clinical trial. Sao Paulo Medical Journal. 129(4), 206-16.

Hawamdeh, M., Al Malty, A.A., Tariah, H.A., Omar, M.H. \& Shtayyat, W.R (2015). Comparison between the Effectiveness of using Transcutaneous Electrical Nerve Stimulation (TENS) with Back Strengthening Exercises and the use of Back Strengthening Exercises only on Patients with Chronic Low Back Pain: a Pilot Crossover Double Blind Study. Indian Journal of Physiotherapy and Occupational Therapy, 9(2), 210-213.

Hernandez-reif, M., Field, T., Krasnegor, J. \& Theakston, H (2001). Lower Back Pain is Reduced and Range of Motion Increased After Massage Therapy. International Journal Neuroscience, 106, 131- 145.

Kuntono, H.P (2005). Nyeri Secara Umum (modul 1). Surakarta: Politeknik Kesehatan Surakarta.

Ogunlana, M .O., Odunaiya, N.A., Dairo, M .D. \& Ihekuna, O (2012). Predictors of Health-related Quality of Life in Patients with 
Non-specific Low Back Pain. Susilowati, S (2011). Aktino Terapi. African Journal of Physiotherapy and Rehabilitation Sciences. 4(1), $15-23$.

Parjoto, S (2006). Terapi Listrik Untuk Modulasi Nyeri. Semarang: Ikatan Fisioterapi Indonesia.

Pattinama, A.A (2013). Low Back Pain (Nyeri Pinggang). Diakses tanggal 18/7/14, dari http://koransindosindo.com/node/309768.

Preyde, M (2000). Effectiveness of massage therapy for subacute lowback pain: a randomized controlled trial. Canadian Medical Association Journal. 162(13), 1815-1820. Surakarta: Politeknik Kesehatan Surakarta, pp:3-6.

Toraman, A.U., Ardahan, M. \& Balyaci, O.E (2014). The effect of the body mechanic behaviors on the low back pain. Nursing Practice Today, 1(2), 107-115.

Walker, B.F. \& Williamson, O.D (2009). Mechanical or inflammatory low back pain. What are thepotential signs and symptoms?. Manual Therapy Journal. 14(3), 314-320. 